\title{
Promotional Mix and Customer Patronage: A Study of Telecom Subscribers in Lagos and Ogun States, Nigeria
}

\author{
Odunlami Samuel Abimbola, Ph.D ${ }^{1}$, Abioro Matthew Adekunle, Ph.D ${ }^{2}$ \\ \& Okeowo Florence Oluremi, Ph.D ${ }^{3}$
}

\author{
${ }^{1}$ Department of Business Administration, Augustine University, Ilara Epe, Lagos State, Nigeria. \\ ${ }^{2}$ Department of Business Administration, Federal University of Agriculture, Abeokuta, Ogun \\ State, Nigeria. \\ ${ }^{3}$ Department of Business Administration and Marketing, Babcock University, Ilishan Remo, \\ Ogun State, Nigeria. \\ Corresponding Author: samuel.odunlami@augustineuniversity.edu.ng
}

Received: 28.02.2020 Accepted: 29.05.2020

Date of Publication: June, 2020

\begin{abstract}
In this present world, a modern telecommunication infrastructural development is not only essential for domestic economic growth, but also a prerequisite for participation in the increasingly competitive world market and for attracting new investments. The main objective of the study is to examine the effect of promotional mix (advertising, sales promotion, public relations, personal selling, and direct marketing) on customer patronage among telecom subscribers in Lagos and Ogun States, Nigeria. Survey research design was used for the study. Data was collected through the use of questionnaire. Descriptive statistics was used to analyze the respondents' biodata while multiple regression analysis was used to test the hypothesis formulated. Findings of the study revealed that advertising, sales promotion, public relations, personal selling, and direct marketing had significant effect on customers' choice of mobile telecommunication network in Lagos and Ogun States, Nigeria. Advertising, sales promotion, public relations, personal selling, and direct marketing had significant effect on customers' expense among telecom subscribers in Lagos and Ogun State. The study concluded that customer patronage will increase in mobile telecommunication firms when they provide adequate information about the services they offer through sufficient advertisements, publicity, personal selling, and direct marketing as well as provide the needed incentives that will encourage rapid purchase of their offers. The study recommended that telecommunication service providers should put in more efforts in their advertisement campaigns, carry out frequent sales promotion programs,
\end{abstract}


build and maintain long lasting relationship with the members of the public, engage more in one-on-one interaction with prospective customers, and give room for customers to make enquiries, lodge their complaints, and offer suggestions on how they can be served better in order to attract more customers and increase their market share.

Keywords: Promotional mix, Advertising, Sales promotion, Public relations, Customer patronage

\section{Introduction}

The world has become a global village with telecommunication being an indispensable tool in the entire process of globalization. In this present world, a modern telecommunication infrastructural development is not only essential for domestic economic growth, but also a prerequisite for participation in the increasingly competitive world market and for attracting new investments. However, it is not in dispute that telecommunication and information technology play essential roles in this process. This is obviously why development in this vital sector over the years has been very phenomenal all over the world. Fortunately, Nigeria has not been left out of this race of rapid development in the telecommunication industry (Ajisola \& Awodun, 2014).

Mobile telecommunication has transformed the way in which people communicate and disseminate information and ideas, especially in developing countries. In Nigeria, the full deregulation of the telecommunication industry in Nigeria paved way for private sector participation in the provision of mobile telecommunication services to citizens of the Nigeria. This led to the licensing of global system for mobile (GSM) communication operations in 2001. Due to the upsurge and speed in the growth of subscribers of the telecommunication industry in Nigeria, the GSM market has given room for intense rivalry among telecom operators (Hashim, 2014).

According to Adeleke and Aminu (2012), GSM revolution commenced in Nigeria in August 2001, when mobile telecom operators such as Econet (now Airtel), Mtel, and MTN were given license by Nigerian Communications Commission (NCC) to provide telecommunication services to Nigerian citizens. Other telecom service providers such as Globacom and Etisalat were later licensed to operate. The operations of these telecom service providers have continued to transform the state of information and communication technology in Nigeria. The astronomical growth in the subscriber base of the GSM operators has led to intense competition in the mobile telecommunications market in Nigeria. This competition is exacerbated by the lower switching costs among the subscribers of the various networks which manifest in the frequency with which the subscribers freely enter and leave the networks.

The deployment of GSM system into Nigerian telecoms market was universally embraced and found to be relatively efficient at the inception. With time, operators in the 
telecommunications

industry experienced an unprecedented growth in customer-base which later incapacitated the networks to function efficiently. This explosive growth brought huge revenue to both the operators and government through tax and license fee (Adegoke \& Babalola, 2011).

According to Oluwafemi and Adebiyi (2018), the Nigerian telecommunication market is deregulated and liberalized, thus making it highly competitive. Therefore, customers should be offered sophisticated products and services in order to keep the firm the heart of subscribers. Products and services should not only be provided to consumers, rather information about such product and service offerings should be effectively communicated to the consumers. To this end, effective use of promotional mix such as advertising, sales promotion, public relations, direct marketing, and personal selling will help telecommunication service providers to provide customers with an in depth understanding of how their products and services will meet and satisfy the needs of customers in order to stimulate and sustain subscribers' patronage that would result in customer loyalty. It is not sufficient for service operators in any competitive market to provide quality service, but it is worthwhile that they communicate within a reasonable budget everything that subscribers need to know about current and future brand in order to take informed decisions favorable to the firm (Oluwafemi \& Adebiyi, 2018).

Nigeria has been ranked the Seventh (7th) position among the top ten countries with the highest number of mobile phone subscription in the world (Wee, 2019). Mobile telecommunication service providers have invested over US $\$ 5.750$ billion into network expansion and provision of better services in order enhance the level of customer satisfaction and customer patronage (Samuel \& Olatokun, 2014). Despite these efforts made by telecom service providers in Nigeria, Nigerians still complain about still complain bitterly about the services provided by telecom operators in terms of high call tariffs, poor voice signals, illegal deduction of airtime for calls not made, poor reception, errors in connection and poor inter-connectivity with other networks among others. Also, Nigerians X-rayed the activities of telecommunications service providers operating in the country, saying they have failed to provide quality service despite having spent lots of money for poor quality service. These complaints are mainly because Nigerians do not enjoy the services provided as stated in the promotional mix of telecom service providers in Nigeria. Consumers have judged the information provided during promotional activities of telecom service operators as misleading and unethical because such information claim do not reflect in the services they offer (Emerah, Oyedele, \& David, 2013; Samuel \& Olatokun, 2014; Ubabukoh, 2014; and Amah, Ogunnaike, Ayeni, \& Ojo, 2017). Hence, customers become dissatisfied and switch from one service provider to the other.

Several studies such as Ismail, Hussain, Shah, and Hussain (2012); Muhanji and Ngari (2015); Nkana and Dafiovo (2015); Onigbinde and Odunlami

URL: http://journals.covenantuniversity.edu.ng/index.php/cjbss 
(2015); Sultan (2015); Abdullah (2016); Jemutai and Wambua (2016); Khanfar (2016); Shamout (2016); Yang and Lee (2016); Egwuonwu, Adeniran, and Egwuonwu (2017); Fasana and Haseena (2017); Shirisha and Sucharitha (2017); Bhatti (2018); Tibebe and Ayenew (2018); Ezenyilimba, Mbah, and Eze (2019); etc. have been conducted on promotional mix and customer patronage. However, to the best knowledge of the researchers, there is paucity of research on promotional mix and customer patronage among telecom subscribers in Lagos and Ogun States, Nigeria. This study filled this gap in knowledge by investigating the effect of promotional mix on customer patronage among telecom subscribers in Lagos and Ogun States, Nigeria. The study also filled the gap in knowledge by examining the combined effect of the independent variables on each of the dependent variable as there exists dearth of research that examined the combined effect of the independent variables on each of dependent variable in the literature.

The main objective of the study is to examine the effect of promotional mix (advertising, sales promotion, public relations, personal selling, and direct marketing) on customer patronage among telecom subscribers in Lagos and Ogun States, Nigeria.

The research hypotheses developed for this study are stated as follows:

H01: Promotional mix (advertising, sales promotion, public relations, personal selling, and direct marketing) has no significant effect on customers' choice of mobile telecommunication network in Lagos and Ogun States, Nigeria.

H02: Promotional mix (advertising, sales promotion, public relations, personal selling, and direct marketing) has no significant effect on customers' expense among telecom subscribers in Lagos and Ogun States, Nigeria.

\section{Review of Related Literature Conceptual Review}

According to Ross (2001), promotional mix can be defined as the totality of marketing communication programs set aside by an organization to communicate the merits of its products and services in the mind of prospective customers. Adebisi (2006) defines promotional mix as a set of marketing activities that provides adequate and accurate information about the benefits of a firm's products and services with the sole aim of inducing consumers to either purchase the products as soon as possible as well as keep buying the products. Fill (2006) defines promotional mix as a management process through which an organization engages with its various audiences. By understanding an audience's communication environment, organizations seek to develop and present messages for its identified stakeholder groups, before evaluating and acting upon the responses. By conveying messages that are of significance value, audiences are encouraged to offer attitudinal and behavioural responses. The primary aim of promotional mix is to stress or place emphasis on the unique importance of a firm's products and services as compared to competitors' offers needed to facilitate the rapid sale 
of such products and services in the market. An enterprise that succeed in emphasizing the unique qualities of its offers will generate high sales turnover and gain an edge over its competitors in the market (Nour, Almahirah, Sultan, \& Sultan, 2014).

Advertising is any paid form of nonpersonal presentation and promotion of ideas, goods or services by an identified sponsor. Mediums of advertising include television, radio, newspapers, magazines, direct mail, billboards, and transit cards (advertisement on buses and taxis and at bus stops). Advertising has the advantage of being able to reach the masses e.g. through television networks but it can also be microtargeted to small groups of potential consumers through print advertisements in magazine (Kotler \& Armstrong, 2001). Advertising is a key element of the promotional activity which has become the undisputed spokesman of modern marketing which is characterized by centralized and mass production, differentiated and branded products, and widely dispersed and sophisticated consumers (OnyenyiliOnuorah, 2005). As stated by Keller (2008), advertising serve as a powerful means of communicating strong, favourable, and unique features of a brand to customers which in turn creates long lasting positive impression about the advertised brand as well drive them to exhibit positive attitudes towards the brand by purchasing it continually.

Sales promotion is a marketing communication tool designed to stimulate immediate purchase of goods and services mainly by the use of incentives. Examples of such incentives include free sample, twin-pack bargain, temporary price reduction, special discount bonus, etc. (Adebisi \& Babatunde, 2011). Blythe (2006) as cited in Idris, Asokere, Ajemunigbohun, Oreshile, and Olutade (2012) describes sales promotion as any activity intended to generate a temporary boost in sales. This includes several communications activities pursued in an attempt to provide added value or incentives to customers, wholesalers, retailers, or other organizational customers to stimulate immediate sales. Such efforts are usually geared towards stimulating product interest, trials or purchase. It is specifically designed to boost quick sales and ultimately create loyalty.

Public relations refer to activities embarked upon by a business firm to create and enhance a favourable image within the industry and society in which it operates. Such activities include press releases, consumer training/education on effective use of products and services, events sponsorships, periodic broadcast on radio stations, television broadcast, and active participation in corporate social responsibility to promote its image within the internal and external publics (Bylon \& Bede, 2013). Good public relations between a firm and its stakeholders enables the firm to capture, maintain, and improve a favourable and positive image in the media and consequently increase its customer patronage. Business enterprises deal with the public, most importantly the internal publics (workers and current customers) who are empowered to be good ambassadors of the organization in the outside world. Customers that derive high value from 
an organization's products purchased and consumed keep patronizing the firm and as well promote the image of the firm favourably through positive word of mouth in the general public (Bylon \& Bede, 2013).

Personal selling involves verbal communication and face-to-face interaction between an organization's sales representatives and prospective buyers in order to disseminate sufficient information, overcome prospects' objections to sale, provide answers to questions asked by prospective customers, and generate a positive response towards the organization's offers. (McCarthy \& Perreault, 2004). This promotional activity can be measured through the level of training and skills possessed and displayed by sales representatives, salesforce's style and appearance, the possibility of providing information, capabilities in solving problems, displaying verbal persuasion, and style presentation (Nour et al., 2014).

Direct marketing refers to all activities performed by the seller to attract potential customers speedily on a oneon-one basis through the use of marketing channels such as telemarketing (telephone calls), text messages, posters and handbills, online advertisements, website visits/surveys and electronic mails. (Stone \& Jacobs, 2007). The objectives of direct marketing include: First, to measure consumers' response to promotional offers by the marketers. Second, to build and maintain long lasting relationship with consumers. Finally, to effectively use modern communication technologies in fostering the deal between sellers and consumers. (AlBakri, 2006). Direct marketing allows an organization to promote its products directly to its target consumers, reach its desired market segments with personalized messages, optimize its marketing budgets, keep in touch with current and new customers, respond to market demand more effectively, and customize its offers to current and prospective customers in order to increase its customer patronage and customer loyalty (Abdullah, 2016).

Consumer buying decision is a series of choices made by consumer before making a purchase. Pride and Ferrell (2012) as cited in Sagala, Destriani, Putri, and Kumar (2014) stated that to understand consumer buying decision, the marketer should understand the consumption process and the utility of products in consumers' perceptions. They also declared that when purchasing products unconsciously, consumer gets through several steps in the making of purchase decision, purchase, and post-purchase evaluation. The first step decision is problem recognition where the consumers are able to differentiate between their needs and wants. Marketers usually use advertising, sales person, and packaging to stimulate recognition of the needs or wants. The second step is information search where the consumer seeks the information from their memory about the products, seeking the information from outside sources, such as from friends, relatives, government reports, publication, sales person, website, packaging label, and display, or by repetition. The third is evaluation of alternatives where the consumer will 
establish criteria which consist of characteristic that are important for them. The fourth step is the purchase decision where the customer decides to buy the product after evaluating among alternatives. The last step is the postpurchase decision where the consumer decides to keep purchasing the product if he is satisfied or stop purchasing the product if he is dissatisfied.

Customer satisfaction refers to customers' evaluation of the experience that was encountered after the consumption of products and services in terms of whether the products and services deliver the benefits expected. Satisfaction of customers' needs is an integral part of any business enterprise because satisfied customers help the firm to generate the revenue needed to carry out its business operations, maximize profit, survive, and gain an edge over its competitors in the market (Hanif, Hafeez \& Riaz, 2010). Building and maintaining profitable customer relationship successfully in any business organization depends on the ability of such firm to satisfy the needs of its customers (Lonial \& Zaim, 2000).

\section{Theoretical Review}

Two theories were reviewed in this study. These theories include AIDA theory and relationship marketing theory.

AIDA is an acronym for awareness, interest, desire and action. This theory states that marketers can attract and retain customers by creating awareness, creating interest, inspiring desire and precipitating the action of prospective buyers towards the purchase of their firm's products and services (Kimmel, 2005). In addition, organizations that creates awareness, interest, desire, and positive customers' attitude towards their products in the market using appropriate channels of communication to reach the mass market will stimulate demand for its products and services as well as gain high level of customer patronage and loyalty from time to time (Mbogo, 2013).

In order to attract more customers always, telecommunication firms must create awareness, stimulate interest, inspire desire, and motivate prospective customers to patronize their offers by making good use of marketing communication mix such as advertising, sales promotion, direct marketing, personal selling, and public relations to inform prospective customers about the services they render. Creating awareness generates interest which in turn will lead the prospective customers to purchase their products and services (Afande \& Maina, 2015).

Relationship marketing theory is a marketing theory developed from direct response marketing campaigns which emphasizes customer retention and satisfaction, rather than just customer patronage (Alexander \& Schouten, 2002). As a practice, relationship marketing differs from other forms of marketing in that it recognizes the longterm value of customer relationships and extends communication beyond intrusive advertising and sales promotional messages (Aaker \& Joachimsthaler, 2000). With the advent and growth of the internet and mobile devices, relationship marketing has continued to evolve and move forward as technology opens more collaborative 
and social communication channels (Berglof \& Bolton, 2002).

Relationship marketing involves a shortterm arrangement where both the buyer and seller have an interest in providing a more satisfying exchange (Adebisi, 2006). Relationship marketing relies upon the communication and acquisition of consumer requirements solely from existing customers in a mutually beneficial exchange usually involving permission for contact by the customer through an "opt-in" system (Adebisi, 2006). With particular relevance to customer satisfaction, the relative price and quality of goods and services produced or sold through a company alongside customer service rendered generally determines the amount of revenue an organization will generate compared with that of its competitors (Berglof \& Bolton, 2002).

A key principle of relationship marketing is the retention of customers through various means and practices to ensure repeated purchase from existing customers by satisfying their needs and wants beyond those of competitors through a mutually beneficial relationship (Albers-Millers \& Straughan, 2000). Telecommunication firms will attract more customers by building and maintaining long lasting relationship with existing customers who in turn will recommend them to members of the public. This can be achieved by providing unique and quality telecommunication services than their competitors in the industry. Telecommunication service providers that succeed in increasing their customer base by delivering unique and quality telecom services than their competitors will generate maximum revenue to carry out their operations, gain an edge over their competitors in the industry as well as gain local and global recognition among top leading telecommunication firms both locally and internationally (Aka, Kehinde, \& Ogunnaike, 2016).

This study is anchored on relationship marketing theory. This is because telecommunication service providers will retain existing customers and attract more customers not only by communicating the benefits they offer but mainly by building and maintaining long lasting relationship with existing customers who in turn will recommend their friends, family, and other members of the public to patronize their telecommunication service providers.

\section{Empirical Review}

Onigbinde and Odunlami (2015) evaluated the influence of brand image and promotional mix on consumer buying decision among beverage consumers in Lagos State, Nigeria. Descriptive survey research design was employed for the study. Descriptive statistics and Pearson Product Moment Correlation Coefficient were used to analyze the data gathered from the respondents. Findings of the study indicated that brand image has a significant influence on consumer buying decision among beverage consumers in Lagos State, Nigeria. Advertising has a significant relationship with consumer buying decision. Sales promotion has a significant influence on consumer buying decision. Finally, personal selling has a significant relationship with consumer buying decision among 
beverage consumers in Lagos State, Nigeria.

Afande and Maina (2015) evaluated the influence of promotional mix elements on sales volume of financial institutions in Kenya using Kenya Post Office Savings Bank as a case study. Descriptive research design was used for the study. This study was carried out in Kenya Post Office Savings Bank headquarters in Nairobi, Kenya. Descriptive statistics, Pearson's Chisquare test, and regression analysis were used to analyze the data gathered from the respondents. The study discovered that sales promotion, personal selling, advertising, public relations, and direct marketing have significant effect on sales volume of financial institutions in Kenya. However, sales promotion has the most significant effect on sales volume.

Enitilo, Ajayi, and Famuagun (2017) evaluated the effect of promotional activities on customer patronage of insurance firms in Ado-Ekiti Metropolis, Ekiti State, Nigeria. The study employed survey research design. The respondents comprised of customers of ten selected insurance firms that have business operating in Ado-Ekiti, Ekiti State. Stratified random sampling technique was used for the study. Descriptive statistics was used to analyze the respondents' demography while inferential statistics (multiple regression analysis) was used to test the hypothesis formulated. Results of the study indicated that media advertising, sales promotion, personal selling, and direct marketing have significant effect on customer patronage of selected insurance firms in Ado-Ekiti Metropolis, Ekiti State, Nigeria.

Shirisha and Sucharitha examined the impact of promotional mix on consumers' purchasing decision. Population of the study comprised of managers, staff, and customers of fastmoving consumer goods (FMCG) companies in Jordan. Primary data was collected with the aid of a questionnaire. Descriptive statistics was used to analyze the respondents' demography and responses on each item of the research instrument while multiple regression analysis was used to test the hypotheses formulated. Findings of the study revealed that advertising, personal selling, sales promotion, publicity, and public relations have no combined significant effect on consumers' purchasing decision. However, advertising has a significant effect on consumers' purchasing decision. Personal selling has a significant effect on consumers' purchasing decision. Sales promotion has a significant effect on consumers' purchasing decision. Publicity has no significant effect on consumers' purchasing decision. Public relations have a significant effect on consumers' purchasing decision.

Khanfar (2016) examined the effect of promotional mix elements used by Umniah Telecommunication Company on consumers' buying decision in Zarqa City, Jordan. Population of the study comprised of consumers of Umniah Telecommunication Company in Zarqa City, Jordan. Convenience sampling technique was used for the study. Primary data was used to collect data from the respondents with the aid of a questionnaire. Descriptive statistics was 
used to analyze the respondents' demography and responses on each item of the research instrument while simple regression analysis and multiple regression analysis were used to test the hypotheses formulated. Results from simple regression analysis showed that advertising, personal selling, sales promotion, and public relations have individual significant effect on consumers' buying decision. However, sales promotion has the most significant effect on consumers' buying decision. Results from multiple regression analysis revealed that advertising, personal selling, sales promotion, and public relations have combined significant effect on consumers' buying decision.

Mahmud, Mohammad, Sultan, and Sultan (2014) examined the impact of promotional activities on consumers' purchasing decision in Jordanian shareholding ceramic and glass production companies. Sample of the study comprised of managers and staff of the marketing department of two Jordanian shareholding ceramic and glass production companies. Questionnaire was used to collect data from the respondents. Descriptive statistics was used to analyze the respondents' demography and responses on each item of the research instrument while multiple regression analysis was used to test the hypotheses formulated. The study found that advertising, personal selling, sales promotion, publicity, and public relations carried out by Jordanian shareholding ceramic and glass production companies had no significant effect on consumers' buying decision. However, advertising, personal selling, and sales promotion have individual significant effect on consumers' purchasing decision while publicity and public relations have no individual significant effect on consumers' purchasing decision.

Oluwafemi and Adebiyi examined the influence of integrated marketing communication dimensions on customer loyalty in the Nigerian telecommunication industry. Population of the study comprised of subscribers of the four telecommunication service providers (MTN, Globacom, Airtel, and 9Mobile) residing in Lagos State, Nigeria. Cross sectional survey research design was used for the study. Multistage sampling technique (cluster, quota, and simple random sampling techniques) was used to select the samples for the study. Questionnaire was used to collect data from the respondents. Descriptive statistics and inferential statistics (correlation and multiple regression analysis) were used to analyze the data collected from the respondents. Results from correlation analysis indicated that there is a significant relationship between integrated marketing communications (advertising, sales promotion, publicity, and direct marketing) and customer loyalty among telecom subscribers in Lagos State, Nigeria. Results from multiple regression analysis affirmed that integrated marketing communications (advertising, sales promotion, publicity, and direct marketing) have combined significant effect on customer loyalty.

Oyedapo, Akinlabi, and Sufian (2012) examined the impact of sales promotion on organization effectiveness in 
Nigerian manufacturing industry. Survey research design was used for the study. Population of the study comprised of management and staff of Nestle Nigeria Plc. both at the head office and manufacturing plants. Descriptive statistics was used to analyze the respondents' demography and responses on each item of the research instrument while Chi-square independence test was used to test the hypotheses formulated. Findings of the study showed that beverage drink industry use sales promotion strategies to achieve their set goals. Also, adoption of sales promotion strategies significantly influence the effectiveness of beverage drink industry.

Abdullah (2016) examined the impact of promotional mix elements on consumers' purchasing decision. Population of the study comprised of consumers in Kurdish, Iran. Simple random sampling technique was used for the study. Questionnaire was used to collect data from the respondents. Descriptive statistics, Pearson product moment, correlation coefficient, and regression analysis were used to analyze the data gathered from the respondents. Results from descriptive statistics showed that promotional mix elements (advertising, sales promotion, personal selling, and direct marketing) stimulate consumers' purchasing decision. Results from Pearson analysis revealed that advertising, sales promotion, personal selling, and direct marketing have individual significant relationship with consumers' purchasing decision. Results from regression analysis affirmed that advertising, sales promotion, personal selling, and direct marketing have individual significant effect on consumers' purchasing decision.

Oghojafor, Ladipo, Ighomereho, and Odunewu (2014) examined the marketing activities that influence customer satisfaction and the factors that determine customer loyalty in the Nigerian telecommunication industry. Telecom subscribers in Lagos State, Nigeria formed the population of the study. Cross sectional survey research design was used for the study. Purposive sampling technique was used for the study. Questionnaire was used to collect data from the respondents. Descriptive statistics was used to analyze the respondents' demography and responses on each item of the research instrument while regression analysis was used to test the hypotheses formulated. The study found that product (core service), promotion, price, distribution, and customer service have individual significant effect on customer satisfaction. Also, customer satisfaction, trust, and social network have individual significant effect on customer loyalty while commitment has no significant effect on customer loyalty.

\section{Research Model}

A research conceptual model was developed to show the effect of the independent variables (advertising, sales promotion, public relations, personal selling, and direct marketing) on each of the dependent variable (customers' choice and customers' expense) among telecom subscribers in Lagos and Ogun States, Nigeria.

\section{URL: http://journals.covenantuniversity.edu.ng/index.php/cjbss}


Independent Variable

Promotional Mix (X)

\section{Dependent Variable}

Customer Patronage (Y)

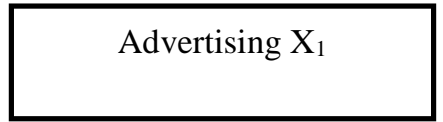

Sales Promotion $\mathrm{X}_{2}$

Public Relations $\mathrm{X}_{3}$

Personal Selling $\mathrm{X}_{4}$

Direct Marketing $\mathrm{X}_{5}$

Source: Researchers' Conceptual Model (2019).

\section{Methodology}

Survey research design was adopted for this study. This was done for three reasons. First, it is capable of obtaining information from large samples of the population. Second, it is well suited in gathering demographic data that describe the composition of the sample (McIntyre, 1999). Third, it is inclusive in the types and number of variables that can be studied; while it requires minimal investment to develop and administer, and is relatively easy for making generalizations (Bell, 1996 cited in Glasow, 2005). The population of this study comprises of subscribers of telecom service providers (MTN, Globacom, Airtel, and 9Mobile) in Lagos and Ogun States, Nigeria. Convenience sampling technique was chosen as the sampling technique for this study. Convenience sampling techniques allows the researcher to select the samples that are readily

URL: http://journals.covenantuniversity.edu.ng/index.php/cjbss 
available and willing to participate in his research study (Latham, 2007). Sample size of the study comprised of Four hundred and seventy (470) telecom subscribers in Lagos and Ogun States, Nigeria.

The research instrument used for this study was a structured questionnaire. The questionnaire enables the respondents to understand the intention of the study. It also enables the researcher to obtain information from the respondents easily (Asika, 2004). The study adapted the questionnaire of Kehinde (2009) on marketing communication mix and Nwanze (2019) on customers' choice and customers' expense. Internal consistency method of reliability was used to test the reliability of the research instrument. Cronbach alpha was used to test the internal consistency of the research instrument. Cronbach alpha co-efficient determines the internal consistency or average correlation of items in a survey research instrument in order to gauge its reliability (Santos, 1999). A value of 0.70 and above shows that the research instrument is reliable (Santos, 1999). The questionnaire comprised of two major sections: Section A (demographic profile of the respondent) and Section B (Research construct items).
The questionnaire comprised of major construct items. However, modified Likert's interval rating scale with options ranging from strongly agree, agree, partially agree, partially disagree, disagree, and strongly disagree were used as the response patterns on the construct items. The pilot study was carried out by administering copies of the questionnaire to Ten (10) percent of the respondents who filled them and returned back to the researchers. Thereafter, the reliability of the research instrument was tested using Cronbach Alpha co-efficient. Four hundred and seventy (470) copies of the questionnaire were administered to customers of telecom service providers in Lagos and Ogun States, Nigeria. Descriptive statistics using simple percentages and frequency distribution tables was used to analyze the respondents' bio-data (gender, age, marital status, and educational qualifications) and responses on each item of the research instrument while multiple regression analysis was used to test the hypotheses formulated. These methods of data analysis were used with the aid of the Statistical Package for the Social Sciences (SPSS) version 23.

The table below shows the Cronbach Alpha value of each item of the research instrument tested: 
Table 1: Cronbach Alpha Value of the Research Instrument

\begin{tabular}{|l|l|l|l|}
\hline Variable & $\begin{array}{l}\text { Number } \\
\text { of Items }\end{array}$ & $\begin{array}{l}\text { Telecom } \\
\text { Subscribers in } \\
\text { Lagos State }\end{array}$ & $\begin{array}{l}\text { Telecom } \\
\text { Subscribers in } \\
\text { Ogun State }\end{array}$ \\
\hline Customers' Choice & 4 & 0.86 & 0.77 \\
\hline Customers' Expense & 4 & 0.90 & 0.84 \\
\hline Advertising & 4 & 0.95 & 0.83 \\
\hline Sales Promotion & 4 & 0.74 & 0.81 \\
\hline Public Relations & 5 & 0.70 & 0.78 \\
\hline Personal Selling & 5 & 0.72 & 0.76 \\
\hline Direct Marketing & 5 & 0.94 & 0.89 \\
\hline Total & 31 & & \\
\hline
\end{tabular}

Source: Researchers' Computation (2019).

The table above shows the Cronbach Alpha value for each item of the research instrument tested which ranged between 0.70 and 0.95 . This shows that the research instrument tested is reliable.

\section{Data Analysis, Results and}

\section{Discussion}

Four hundred and seventy (470) copies of questionnaire were administered to telecom subscribers in Lagos and Ogun States, Nigeria, out of which only Four hundred and five (405) copies were filled and returned.

Table 2: Analysis of Questionnaire Distribution and Retrieval Rate

\begin{tabular}{|l|l|l|}
\hline & FREQUENCY & PERCENTAGE (\%) \\
\hline Retrieved & 405 & 86 \\
\hline Not Retrieved & 65 & 14 \\
\hline TOTAL & $\mathbf{4 7 0}$ & $\mathbf{1 0 0}$ \\
\hline
\end{tabular}

Source: Researchers' Field Survey (2019)

Table 3 above shows that 405 $(86 \%)$ of the respondents filled and returned the questionnaire, while
$65(14 \%)$ of the respondents did not return the questionnaire. Thus, the percentage of questionnaires

URL: http://journals.covenantuniversity.edu.ng/index.php/cjbss 
returned is high enough for the this research work. generalization of the outcome of

Table 3: Analysis of the Respondents' Demography

\begin{tabular}{|l|l|l|}
\hline VARIABLE & FREQUENCY & PERCENTAGE (\%) \\
\hline GENDER & & \\
\hline Male & 183 & 45.3 \\
\hline Female & 222 & 54.7 \\
\hline Total & 405 & 100 \\
\hline MARITAL STATUS & & \\
\hline Single & 207 & 51.1 \\
\hline Married & 198 & 48.9 \\
\hline Total & 405 & 100 \\
\hline AGE & & \\
\hline 16-20 & 36 & 8.9 \\
\hline 21-30 & 147 & 36.3 \\
\hline 31-40 & 168 & 41.5 \\
\hline 41-50 & 42 & 10.4 \\
\hline 51 and above & 12 & 3 \\
\hline Total & 405 & 100 \\
\hline $\begin{array}{l}\text { EDUCATIONAL } \\
\text { QUALIFICATION }\end{array}$ & & \\
\hline WASSCE & 81 & 20 \\
\hline Bachelor's Degree & 246 & 60.7 \\
\hline Master's Degree & 69 & 17 \\
\hline Doctorate Degree & 9 & 2.2 \\
\hline Total & 405 & 100 \\
\hline $\begin{array}{l}\text { MOST } \\
\text { PREFERRED/USED } \\
\text { NETWORK }\end{array}$ & & \\
\hline Glo & 51 & \\
\hline Airtel & 96 & 12.6 \\
\hline MTN & 228 & 23.7 \\
\hline 9Mobile & 30 & 56.3 \\
\hline Total & 405 & 7.4 \\
\hline $\begin{array}{l}\text { NETWORK USAGE } \\
\text { PERIOD }\end{array}$ & & 100 \\
\hline Less than 6 months & 72 & \\
\hline 6 months to 1 year & 27 & 6.7 \\
\hline 1-3years & 36 & 21.5 \\
\hline 3-5years & 87 & 100 \\
\hline 6 years and Above & 183 & \\
\hline Total & 405 & \\
\hline LEVEL OF & & \\
\hline & & \\
\hline
\end{tabular}

URL: http://journals.covenantuniversity.edu.ng/index.php/cjbss 


\begin{tabular}{|l|l|l|}
\hline $\begin{array}{l}\text { ACTIVENESS ON } \\
\text { MOST } \\
\text { PREFERRED/USED } \\
\text { NETWORK }\end{array}$ & & \\
\hline Less Active & 6 & \\
\hline Active & 54 & 1.5 \\
\hline Very Active & 345 & 13.3 \\
\hline Total OF & 405 & 85.2 \\
\hline $\begin{array}{l}\text { STATE } \\
\text { RESIDENCE }\end{array}$ & 100 \\
\hline Lagos & 237 & \\
\hline Ogun & 168 & 58.5 \\
\hline Total & 405 & 41.5 \\
\hline
\end{tabular}

Source: Researchers' Field Survey (2019).

From the analysis of respondents' demography, $183(45.3 \%)$ of the respondents are male while $222(54.7 \%)$ are female. The marital status showed that $207(51.1 \%)$ of the respondents are single while 198 (48.9\%) are married. The age distribution of respondents showed that $36(8.9 \%)$ of the respondents are within the age of 16-20 years, $147(36.3 \%)$ are within the age of 21-30 years, $168(41.5 \%)$ are within the ages of 31-40 years, $42(10.4 \%)$ are within the age of 41-50 years, and 12 (3\%) are within the age of 51 years and above. The educational qualification showed that $81 \quad(20 \%)$ of the respondents are Senior School Certificate (SSCE) holders, $246(60.7 \%)$ are Bachelor's degree holders, 69 (17\%) are Master's degree holders, and 9 (2.2\%) are Doctorate degree holders. In terms of most preferred/used network of respondents, $51 \quad(12.6 \%)$ of the respondents are Glo subscribers, 96 (23.7\%) are Airtel subscribers, 228 $(56.3 \%)$ are MTN subscribers, and 30 (7.4\%) are 9Mobile subscribers. In terms of network usage period, 72 $(17.8 \%)$ of the respondents have used their network for less than 6 months, 27 $(6.7 \%)$ have used their telecom network for 6 months to 1 year, $36(8.9 \%)$ have used their telecom network for 1-3 years, $87(21.5 \%)$ have used their network for 3-5 years, and 183 (45.2\%) have used their network for 6 years and above. The table above revealed that 6 $(1.5 \%)$ are less active on their telecom network, $54(13.3 \%)$ are active on their telecom network, and $345(85.2 \%)$ are very active on their telecom network. The state of residence showed that 237 $(58.5 \%)$ of the respondents reside in Lagos State while $168(41.5 \%)$ reside in Ogun State.

Findings of the study showed that advertising $(\beta=0.093, \mathrm{t}=0.694$, $p>0.05)$ had no significant effect on customers' choice, sales promotion $(\beta=$ $0.168, \mathrm{t}=1.900, \mathrm{p}>0.05)$ had no significant effect on customers' choice, public relations $(\beta=0.180, \mathrm{t}=1.082$, $\mathrm{p}>0.05)$ had no significant effect on customers' choice, personal selling ( $\beta=$ $0.092, \mathrm{t}=0.878, \quad \mathrm{p}>0.05)$ had no significant effect on customers' choice while direct marketing $(\beta=0.030, \mathrm{t}=$ $0.234, p>0.05$ ) had no significant effect

URL: http://journals.covenantuniversity.edu.ng/index.php/cjbss 
on customers' choice of mobile telecommunication network in Lagos State, Nigeria. The adjusted R square of 0.184 showed that promotional mix (advertising, sales promotion, public relations, personal selling, and direct marketing) explained only $18.4 \%$ of the variation in customers' choice of mobile telecommunication network in Lagos State. This implies that $18.4 \%$ of the changes in customers' choice could be attributed to promotional mix of mobile telecom service providers. The results indicated that the overall model was statistically significant as represented by $\mathrm{F}=4.650$ with $\mathrm{p}$-value $(0.001)<0.05$.

The regression model indicated that holding promotional mix to a constant zero, customers' choice would be 6.617 which implies that without promotional mix, customers' choice of mobile telecommunication network in Lagos State was 6.617. Based on these findings, the null hypothesis $\left(\mathrm{H}_{01}\right)$ which states that promotional mix (advertising, sales promotion, public relations, personal selling, and direct marketing) have no significant effect on customers' choice of mobile telecommunication network in Lagos State is hereby rejected.

Findings of the study showed that advertising $(\beta=0.351, \mathrm{t}=1.830$, $\mathrm{p}>0.05)$ had no significant effect on customers' choice, sales promotion $(\beta=$ $0.025, \mathrm{t}=0.201, \mathrm{p}>0.05)$ had no significant effect on customers' choice, public relations $(\beta=0.238, \mathrm{t}=1.200$, $\mathrm{p}>0.05)$ had no significant effect on customers' choice, personal selling ( $\beta=$ $0.230, \mathrm{t}=1.781, \mathrm{p}>0.05)$ had no significant effect on customers' choice while direct marketing $(\beta=-0.152, \mathrm{t}=$ -
0.903, $\mathrm{p}>0.05$ ) had no significant effect on customers' choice of mobile telecommunication network in Ogun State, Nigeria. The adjusted R square of 0.208 showed that promotional mix (advertising, sales promotion, public relations, personal selling, and direct marketing) explained only $20.8 \%$ of the variation in customers' choice of mobile telecommunication network in Ogun State. This implies that $20.8 \%$ of the changes in customers' choice could be attributed to promotional mix of mobile telecom service providers. The results indicated that the overall model was statistically significant as represented by $\mathrm{F}=3.728$ with $\mathrm{p}$-value $(0.006)<0.05$.

The regression model indicated that holding promotional mix to a constant zero, customers' choice would be 3.045 which implies that without promotional mix, customers' choice of mobile telecommunication network in Ogun State was 3.045. Based on these findings, the null hypothesis $\left(\mathrm{H}_{01}\right)$ which states that promotional mix (advertising, sales promotion, public relations, personal selling, and direct marketing) have no significant effect on customers' choice of mobile telecommunication network in Ogun State is hereby rejected.

Findings of the study showed that advertising $(\beta=0.288, \mathrm{t}=1.442$, $p>0.05)$ had no significant effect on customers' expense, sales promotion ( $\beta$ $=-0.035, \mathrm{t}=-0.337, \mathrm{p}>0.05)$ had no significant effect on customers' expense, public relations $(\beta=-0.173, \mathrm{t}=$ $-0.889, p>0.05$ ) had no significant effect on customers' expense, personal selling $(\beta=0.439, \mathrm{t}=3.582, \mathrm{p}<0.05)$ had $\mathrm{a}$ significant effect on customers' expense 
while direct marketing $(\beta=0.042, \mathrm{t}=$ $0.284, p>0.05$ ) had no significant effect on customers' expense among telecom subscribers in Lagos State, Nigeria. The adjusted $\mathrm{R}$ square of 0.200 showed that promotional mix (advertising, sales promotion, public relations, personal selling, and direct marketing) explained only $20 \%$ of the variation in customers' expense among telecom subscribers in Lagos State. This implies that $20 \%$ of the changes in customers' expense among telecom subscribers in Lagos State could be attributed to promotional mix of mobile telecom service providers. The results indicated that the overall model was statistically significant as represented by $\mathrm{F}=5.060$ with p-value $(0.000)<0.05$.

The regression model indicated that holding promotional mix to a constant zero, customers' expense would be 6.610 which implies that without promotional mix, customers' expense among telecom subscribers in Lagos State was 6.610. Based on these findings, the null hypothesis $\left(\mathrm{H}_{02}\right)$ which states that promotional mix (advertising, sales promotion, public relations, personal selling, and direct marketing) have no significant effect on customers' expense among telecom subscribers in Lagos State is hereby rejected.

Findings of the study showed that advertising $(\beta=-0.230, \mathrm{t}=-1.213$, $p>0.05)$ had no significant effect on customers' expense, sales promotion ( $\beta$ $=-0.068, \mathrm{t}=-0.561, \mathrm{p}>0.05)$ had no significant effect on customers' expense, public relations $(\beta=0.431, \mathrm{t}=$ 2.198, $\mathrm{p}<0.05$ ) had a significant effect on customers' expense, personal selling $(\beta=0.416, \mathrm{t}=3.264, \mathrm{p}<0.05)$ had $\mathrm{a}$ significant effect on customers' expense while direct marketing $(\beta=-0.112, \mathrm{t}=$ $0.675, p>0.05$ ) had no significant effect on customers' expense among telecom subscribers in Ogun State, Nigeria. The adjusted R square of 0.178 showed that promotional mix (advertising, sales promotion, public relations, personal selling, and direct marketing) explained only $17.8 \%$ of the variation in customers' expense among telecom subscribers in Ogun State. This implies that $17.8 \%$ of the changes in customers' expense in Ogun State could be attributed to promotional mix of mobile telecom service providers. The results indicated that the overall model was statistically significant as represented by $\mathrm{F}=3.259$ with $\mathrm{p}$-value $(0.013)<0.05$.

The regression model indicated that holding promotional mix to a constant zero, customers' expense would be 4.914 which implies that without promotional mix, customers' expense among telecom subscribers in Ogun State was 4.914. Based on these findings, the null hypothesis $\left(\mathrm{H}_{02}\right)$ which states that promotional mix (advertising, sales promotion, public relations, personal selling, and direct marketing) have no significant effect on customers' expense among telecom subscribers in Ogun State is hereby rejected.

Results of the study confirmed that promotional mix (advertising, sales promotion, public relations, personal selling, and direct marketing had a significant effect on customers' choice of mobile telecommunication network in Lagos and Ogun States, Nigeria. This implies that efforts made by

\section{URL: http://journals.covenantuniversity.edu.ng/index.php/cjbss}


telecommunication firms in carrying out consistent advertisement, sales promotion, public relations, personal selling, and direct marketing with regard to the services they provide will go a long way to attract more customers and retain their existing customers. Telecommunication service providers that constantly create awareness about the services they offer, provide good incentives to stimulate immediate purchase of their products and services, build and maintain good name and reputation in the public, give room for one-on-one interactions with prospective customers, and give prospective and current customers the opportunity to have access to online information about the services they render will continually drive in customers faster than their competitors. This in turn will help them generate the revenue needed to increase their profit and expand their business. Findings of the study is in congruence with the study of Odunlami and Onigbinde which found that promotional mix (advertising, sales promotion, and personal selling) has significant influence on consumer buying decision. Also, findings of the study support the study of Afande and Maina (2015) which affirmed that advertising, sales promotion, public relations, personal selling, and direct marketing have significant effect on sales volume of financial institutions. Findings of the study contradict the study of Shirisha and Sucharitha (2017) which showed that advertising, personal selling, sales promotion, publicity, and public relations have no significant effect on consumers' purchasing decision.
Results of the study indicated that promotional mix (advertising, sales promotion, public relations, personal selling, and direct marketing had a significant effect on customers' expense among telecom subscribers in Lagos and Ogun States, Nigeria. Findings of the study agree with the study of Enitilo, Ajayi, and Famuagun (2017) which confirmed that media advertising, sales promotion, personal selling, and direct marketing have significant effect on customer patronage. Also, results of the study support the study of Khanfar (2016) which discovered that advertising, personal selling, sales promotion, and public relations have significant effect on consumers' buying decision. Results of the study contradict the findings of Mahmud, Mohammad, Sultan, and Sultan (2014) which found that advertising, personal selling, sales promotion, publicity, and public relations have no significant effect on consumers' buying decision.

\section{Conclusion and Recommendations}

Based on the findings of this study, this study concluded that customer patronage will increase in mobile telecommunication firms when they provide adequate information about the services they offer through sufficient advertisements, publicity, personal selling, and direct marketing as well as provide the needed incentives that will encourage rapid purchase of their offers. Also, telecommunication service providers that take time to build and maintain a good public image will influence customers to purchase their product offers and gain an edge over their competitors speedily and steadily. Mobile telecom service providers that 
commit their time, energy, and resources towards communicating the merits of the products and services they offer, providing a forum that enables customers to make enquiries and clarifications always, creating long lasting impression about themselves in the minds of current and future customers, and persuading customers to purchase their offers immediately will generate the market share required for their expansion and growth both locally and internationally.

The study recommended that telecommunication service providers should put in more efforts in their advertisement campaigns, carry out frequent sales promotion programs, build and maintain long lasting relationship with the members of the public, engage more in one-on-one interaction with prospective customers,

\section{References}

Aaker, D. A., \& Joachimasthaler, E. (2000). Brand leadership. New York: The Free Press.

Abdullah, J. A. (2016). The impact of promotional mix elements on consumer purchasing decisions. Journal for Studies in Management and Planning, 2(1), 171-179.

Adebisi, Y. (2006). Essential of marketing management. Lagos, Nigeria: Cilgal Publication.

Adebisi, S. A., \& Babatunde, B. O. (2011). Strategic influence of promotional mix on organizational sales turnover in the face of strong competitors. and give room for customers to make enquiries, lodge their complaints, and offer suggestions on how they can be served better. This in turn will help in attracting more customers as well as increasing their market share because current customers will remain loyal to them and more customers will begin to patronize them. Telecommunication firms should provide adequate and accurate information about the products and services they offer on television, newspapers, radio, and different social media platforms (twitter, facebook, whatsapp, and instagram) continually. Finally, telecommunication service providers should invest more in sponsoring popular events (trade fair exhibitions, sporting events, arts, and entertainment) to create awareness about the services they provide and capture more market.

Business Intelligence Journal, 4(2), 343-350.

Adegoke, A. S., \& Babalola, I. T. (2011). Quality of service analysis of GSM telephone system in Nigeria.

American Journal of Scientific and Industrial Research, 2(5), 707-712.

Adeleke. A., \& Aminu, S. A. (2012). The determinants of customer loyalty in Nigeria's GSM market. International Journal of Business and Social Sciences, 3(14), 209222.

Afande, F. O., \& Maina, M. P. (2015). Effect of promotional mix elements on sales volume of financial institutions in Kenya:

URL: http://journals.covenantuniversity.edu.ng/index.php/cjbss 
Case study of Kenya Post Office Savings Bank. Journal of Marketing and Consumer Research, 11, 64-91.

Ajisola, K. T., \& Awodun, M. A. (2014). Impact of telecommunication system in Ekiti State, Nigeria.

International Journal of Scientific Research Publications, 4(9), 1-7.

Aka, D. O., Kehinde, O. J., \& Ogunnaike, O. O. (2016). Relationship marketing and customer satisfaction: A conceptual perspective. Binus Business Review, 7(2), 185-190.

Albers-Millers, N. D., \& Straughan, R. D. (2000). Financial services advertising in eight Non English-speaking countries. International Journal of Bank Marketing, 18(7), 347-358.

Al-Bakri, T. (2006). Marketing: The foundations of contemporary concepts. Amman: AlYazouri for Scientific Publishing and Distribution.

Alexander, J. H., Schouten, J. W., \& Koenig, H. F. (2002). Building brand community. Journal of Marketing, 66(1), 38-54.

Amah, E., Ogunnaike, O. O., Ayeni, A. W., \& Ojo, M. (2017). A thematic analysis of advertisement in the telecommunication industry. Binus Business Review, 8(3), 221228.

Asika, N. (2004). Research methodology: A process approach. Nigeria: Mukugamu and Brothers Enterprises.

Berglof, E., \& Bolton, H. (2002). The great divine and beyond:
Financial architecture in transition. Transition Newsletter, 13(6), 8-12.

Bhatti, A. (2018). Sales promotion and price discount effect on consumer purchase intention with the moderating role of social media in Pakistan. International Journal of Business Management (Seiersberg), 3(4), 50-58.

Egwuonwu, T. K., Adeniran, J. A., \& Egwuonwu, C. O. K. (2017). Integrated marketing communications and customer loyalty in Nigeria's telecommunications industry. International Business and Management, 14(2), 18-28.

Emerah, A. A., Oyedele, S. O., \& David, J. O. (2013). Determinants of customer satisfaction in the Nigerian telecommunication industry: An empirical evidence. International Journal of Management and Strategy, 4(6), 1-12.

Enitilo, O., Ajayi, I. E., \& Famuagun, F. Y. (2017). Influence of promotional activities on consumers' patronage of insurance business in Ado-Ekiti Metropolis, Nigeria. International Journal of Economics, Commerce, and Management, 5(1), 414-436.

Ezenyilimba, E., Mbah, C. C., \& Eze, J. O. (2019). Effect of sales promotion on customer patronage of alcoholic beverages in Aguata Local Government Area. International Journal of Research in Management Fields, 3(4), 32-42.

URL: http://journals.covenantuniversity.edu.ng/index.php/cjbss 
Fasana, S. F., \& Haseena, A. G. (2017). Promotional mix as the strategic tool for improving brand equity (A case in franchise fast food restaurants in Sri Lanka). International Journal of Engineering and Management Research, 7(6), 6-11.

Fill, C. (2006). Marketing communications, engagement, strategies, and practices. (4 ${ }^{\text {th }}$ ed.). Edinburgh Gate: Pearson Education Limited.

Glasow, P. A. (2005). Fundamentals of survey research methodology. United States of America: Mitre Publishers.

Hanif, M., Hafeez, S., \& Riaz, A. (2010). Factors affecting customer satisfaction. International Research Journal of Finance and Economics, 60, 4452.

Hashim, Y. A. (2014). Determinants of customer loyalty among subscribers of global system for mobile (GSM) communication in North-Western, Nigeria. The 2014 West East Institute International Academic Conference Proceedings, New Orleans, United States of America, 119-130.

Idris, A. A., Asokere, A. S., Ajemunigbohun, S. S., Oreshile, A. S., \& Olutade, E. O. (2012). An empirical study of the efficacy of marketing communication mix elements in selected insurance companies in Nigeria. Australian Journal of Business and Management Research, 2(5), 818.
Ismail, K., Hussain, J., Shah, F. A., \& Hussain, A. (2012). Effect of marketing communication on sales performance of multinational companies: A case study of Proctor and Gamble Company. Research Journal of Recent Sciences, 1(12), 44-48.

Jemutai, C. R., \& Wambua, P. P. (2016). Integrated marketing communication and performance of Kenya Post and Savings Bank. Social Sciences, 5(3), 37-49.

Kehinde, O.J. (2009). Integrated marketing communications and consumers' patronage of Nigerian beverage products. (Doctoral Dissertation, Covenant University, Ota, OgunState,Nigeria).Retrievedfro mwww.dspace.covenantuniversit y.edu.ng/.../CU03GP0024 \%20$\% 20$ Kehinde $\% 2$

Keller, K. L. (2008). Strategic brand management: Building, measuring, and managing brand equity. New Delhi: Dorling Kindersley.

Khanfar, I. A. (2016). The effect of promotion mix elements on consumers' buying decisions of mobile service: The case of Umniah Telecommunication Company at Zarqa City, Jordan. European Journal of Business and Management, 8(5), 94-100.

Kimmel, A. J. (Ed). (2005). Marketing communication: New approaches, technologies, and styles. London: Oxford University Press.

Korkeamaki, J. (2014). Attracting new customers and retaining current customers through integrated 
marketing communications (Bachelor's Degree Project, University of Applied Sciences, Hagaa-Helia, Finland). Retrieved from

https://www.theseus.fi/bitstream/ handle/10024/76532/Korkeamaki _Jennifer.pdf?sequence $=1$ \&isAllo wed $=\mathrm{y}$

Kotler, P., \& Armstrong, G. (2001). Principles of marketing. ( $4^{\text {th }} \mathrm{ed}$.). New Jersey: Pearson Education Inc.

Latham, B. (2007). Sampling: what is it? Retrieved from www.webpages.acs.ttu.edu/ riatham/.../Sampling_Methodolog y_Paper.pdf

Lonial, S. C., \& Zaim, S. (2000). Investigating of product attributes and their effect on overall satisfaction. Retrieved from www.opf.slu.cz/wr/akce/turecko/ pdf/Lonial.pdf

McCarthy, J., \& Perreault, W. D. (Jnr). (2004). Basic marketing. (5 $5^{\text {th }}$ ed.). Burr Ridge, IL: Irwin

McInytre, L. J. (1999). The practical skeptic: Core concepts in sociology. Mountain View, CA: Mayfield Publishing.

Mahmud, I., Nour, M. S. A., Sultan, M. S., \& Sultan, F. (2014). The impact of promotional mix elements on consumers' purchasing decisions. International Business and Management, 8(2), 143-151.

Mbogo, P. K. (2013). Influence of promotion mix strategies on the growth of customers of pathologists in Lancet, Kenya (Master's Dissertation, University of Nairobi, Nairobi, Kenya).Retrieved from https://www.chss.uonbi.ac.ke/site s/.../Mbogo\%20Final\%20 project\%20november\%202013.pd $\mathrm{f}$

Muhanji, E. M., \& Ngari, B. (2015). Influence of integrated marketing communication and sales performance of commercial banks in Kenya. International Journal of Scientific and Research Publications, 5(9), 1-20.

Nkana, N. S., \& Dafiovo, J. O. (2015). Integrated marketing communications and customer patronage of Etisalat products in Uyo, Nigeria. International Journal of Education and Research, 3(10), 77-94.

Nour, M. I., Almahirah, M. S., Sultan, M. S., \& Sultan, F. (2014). The impact of promotional mix elements on consumer purchasing decisions. International Business and Management, 8(2), 143-151.

Nwanze, C. N. (2019). Advertising and customer brand preference of telecommunication network among university students in Lagos State, Nigeria. Unpublished B.Sc Project Done at Augustine University, Ilara Epe, Lagos State, Nigeria.

Oghojafor, B. E. A., Ladipo, K. A. P., Ighomereho, O. S., \& Odunewu, A. V. (2014). Determinants of customer satisfaction and loyalty in the Nigerian telecommunication industry. British Journal of Marketing Studies, 2(5), 67-83. 
Oluwafemi, A. J., \& Adebiyi, S. O. (2018). Customer loyalty and integrated marketing communications among subscribers of telecommunication firms in Lagos Metropolis, Nigeria. Journal of Competitiveness, 10(3), 101-118.

Onigbinde, I. O., \& Odunlami, S. A. (2015). The influence of brand image and promotional mix on consumer buying decision: A study of beverage consumers in Lagos State, Nigeria. British Journal of Marketing Studies, 3(4), 97-109.

Onyenyili-Onuorah, J. (2005). Advertising and society: Contemporary socio-economic issues in advertising and public relations. Lagos, Nigeria: Raindrops Limited.

Oyedapo, W. O., Akinlabi, B. H., \& Sufian, J. B. (2012). The impact of sales promotion on organization effectiveness in Nigerian manufacturing industry. Universal Journal of Marketing and Business Research, 1(4), 123-131.

Ross, T. (2001). Marketing as a concept. New York: Practice Hall Press.

Sagala, C., Destriani, M., Putri, U. K., \& Kumar, S. (2014). Influence of promotional mix and price on customer buying decision towards fast food sector: A survey on university students in Jabodetabek (Jakarta, Bogor, Depok, Tangerang, Bekasi). Indonesia. International Journal of Scientific and Research Publications, 4(1), 1-7.

Samuel, N. O., \& Olatokun, W. (2014). Telecommunication services provision in Nigeria: Consumers' perspectives on information provision, advertising, and representation of services. African Journal of Computing and ICT, 7(5), 63-76.

Santos, J. R. A. (1999). Cronbach's alpha: a tool for assessing the reliability of scales. Journal of Extension, 37(2), 1-6.

Shamout, M. D. (2016). The impact of promotional tools on consumer buying behavior in retail market. International Journal of Business and Social Science, 7(1), 75-85.

Shirisha, M., \& Sucharitha, D. (2017). The impact of promotional mix on consumers' purchasing decisions. Inspira-Journal of Commerce, Economics, and Computer Science, 3(3), 145-152.

Stone, B., \& Jacobs, R. (2007). Successful direct marketing methods. ( $7^{\text {th }}$ ed.). Chisinau: ARC Publishing House.

Sultan, S. (2015). An analysis of the impacts of effective promotional mix strategies on the customer loyalty and growth of sales: A study on Agora Limited. Journal of Business Studies, 36(2), 143156.

Tibebe, G., \& Ayenew, T. (2018). The effectiveness of integrated marketing communication for high involvement product purchase decision: In case of University of Gondar employees. 
Pacific Business Review

International, 11(4), 17-29.

Ubabukoh, O. (2014). Poor telecoms service persists despite N1.8billion fine. Punch Newspaper on Tuesday September 23, 2014.

Wee, R. Y. (2019). 10 countries with the highest rates of cell phone subscriptions in the world. Retrieved from https://www.worldatlas.com/articl es/10-countries-with-the-highestrates- of-cell-phonesubscriptions.html

Yang, D., \& Lee, C. W. (2016). In-store promotional mix and the effects on female consumer buying decisions in relation to cosmetic products. International Journal of Management, Economics, and Social Sciences, 5(2), 35-56.

\section{Model Summary}

\begin{tabular}{|l|c|r|r|r|}
\hline Model & \multicolumn{1}{|c|}{$\mathrm{R}$} & \multicolumn{1}{|c|}{ R Square } & $\begin{array}{c}\text { Adjusted R } \\
\text { Square }\end{array}$ & $\begin{array}{c}\text { Std. Error of the } \\
\text { Estimate }\end{array}$ \\
\hline 1 & $.484^{\mathrm{a}}$ & .234 & .184 & 3.33594 \\
\hline
\end{tabular}

a. Predictors: (Constant), Direct Marketing, Sales Promotion, Personal Selling, Advertising, Public Relations

ANOVA $^{\mathrm{a}}$

\begin{tabular}{|ll|r|r|r|r|r|}
\hline Model & & Sum of Squares & df & Mean Square & F & Sig. \\
\hline 1 & Regression & 258.721 & 5 & 51.744 & 4.650 & $.001^{\mathrm{b}}$ \\
& Residual & 845.767 & 76 & 11.129 & & \\
& Total & 1104.488 & 81 & & & \\
\hline
\end{tabular}

a. Dependent Variable: Customers' Choice

b. Predictors: (Constant), Direct Marketing, Sales Promotion, Personal Selling, Advertising, Public Relations

Coefficients $^{\mathrm{a}}$

\begin{tabular}{|c|c|c|c|c|c|}
\hline \multirow[b]{2}{*}{ Model } & \multicolumn{2}{|c|}{$\begin{array}{l}\text { Unstandardized } \\
\text { Coefficients }\end{array}$} & \multirow{2}{*}{$\begin{array}{c}\text { Standardized } \\
\text { Coefficients } \\
\text { Beta }\end{array}$} & \multirow[b]{2}{*}{$\mathrm{t}$} & \multirow[b]{2}{*}{ Sig. } \\
\hline & B & Std. Error & & & \\
\hline $1 \quad$ (Constant) & 6.617 & 2.559 & & 2.586 & .012 \\
\hline Advertising & .093 & .134 & .099 & .694 & .490 \\
\hline $\begin{array}{l}\text { Sales } \\
\text { Promotion }\end{array}$ & .168 & .088 & .213 & 1.900 & .061 \\
\hline $\begin{array}{l}\text { Public } \\
\text { Relations }\end{array}$ & .180 & .166 & .176 & 1.082 & .283 \\
\hline $\begin{array}{l}\text { Personal } \\
\text { Selling }\end{array}$ & .092 & .104 & .114 & .878 & .383 \\
\hline $\begin{array}{l}\text { Direct } \\
\text { Marketing }\end{array}$ & .030 & .126 & .033 & .234 & .815 \\
\hline
\end{tabular}

a. Dependent Variable: Customers' Choice 
Model Summary

\begin{tabular}{|l|r|r|r|c|}
\hline Model & $\mathrm{R}$ & R Square & \multicolumn{1}{|c|}{$\begin{array}{c}\text { Adjusted R } \\
\text { Square }\end{array}$} & $\begin{array}{c}\text { Std. Error of the } \\
\text { Estimate }\end{array}$ \\
\hline 1 & $.500^{\mathrm{a}}$ & .250 & .200 & 3.92042 \\
\hline
\end{tabular}

a. Predictors: (Constant), Direct Marketing, Sales Promotion, Personal Selling, Advertising, Public Relations

\begin{tabular}{|c|c|c|c|c|c|}
\hline \multicolumn{6}{|c|}{ ANOVA $^{a}$} \\
\hline Model & Sum of Squares & $\mathrm{df}$ & Mean Square & $\mathrm{F}$ & Sig. \\
\hline 1 Regression & 388.842 & 5 & 77.768 & 5.060 & $.000^{\mathrm{b}}$ \\
\hline Residual & 1168.097 & 76 & 15.370 & & \\
\hline Total & 1556.939 & 81 & & & \\
\hline
\end{tabular}

a. Dependent Variable: Customers' Expenses

b. Predictors: (Constant), Direct Marketing, Sales Promotion, Personal Selling, Advertising, Public Relations

\section{Coefficients $^{\mathrm{a}}$}

\begin{tabular}{|c|c|c|c|c|c|}
\hline \multirow[b]{2}{*}{ Model } & \multicolumn{2}{|c|}{$\begin{array}{l}\text { Unstandardized } \\
\text { Coefficients }\end{array}$} & \multirow{2}{*}{$\begin{array}{c}\text { Standardized } \\
\text { Coefficients } \\
\text { Beta }\end{array}$} & \multirow[t]{2}{*}{$\mathrm{t}$} & \multirow[t]{2}{*}{ Sig. } \\
\hline & $\mathrm{B}$ & Std. Error & & & \\
\hline 1 (Constant) & 6.610 & 3.007 & & 2.198 & .031 \\
\hline Advertising & .228 & .158 & .203 & 1.442 & .153 \\
\hline Sales Promotion & -.035 & .104 & -.037 & -.337 & .737 \\
\hline Public Relations & -.173 & .195 & -.143 & -.889 & .377 \\
\hline Personal Selling & .439 & .123 & .458 & 3.582 & .001 \\
\hline Direct Marketing & .042 & .148 & .039 & .284 & .777 \\
\hline
\end{tabular}

a. Dependent Variable: Customers' Expenses

\begin{tabular}{|l|c|r|r|c|}
\multicolumn{5}{|c|}{ Model Summary } \\
\hline Model & $\mathrm{R}$ & $\mathrm{R}$ Square & $\begin{array}{c}\text { Adjusted R } \\
\text { Square }\end{array}$ & $\begin{array}{c}\text { Std. Error of the } \\
\text { Estimate }\end{array}$ \\
\hline 1 & $.533^{\mathrm{a}}$ & .284 & .208 & 3.75612 \\
\hline
\end{tabular}

a. Predictors: (Constant), Direct Marketing, Sales Promotion, Personal Selling, Public Relations, Advertising

ANOVA $^{\mathrm{a}}$

\begin{tabular}{|ll|c|c|c|c|c|}
\hline Model & & Sum of Squares & $\mathrm{df}$ & Mean Square & $\mathrm{F}$ & Sig. \\
\hline 1 & Regression & 262.979 & 5 & 52.596 & 3.728 & $.006^{\mathrm{b}}$ \\
& Residual & 663.097 & 47 & 14.108 & & \\
& Total & 926.075 & 52 & & & \\
\hline
\end{tabular}

a. Dependent Variable: Customers' Choice

b. Predictors: (Constant), Direct Marketing, Sales Promotion, Personal Selling, Public Relations, Advertising

URL: http://journals.covenantuniversity.edu.ng/index.php/cjbss 


\section{Coefficients $^{a}$}

\begin{tabular}{|c|c|c|c|c|c|c|}
\hline \multirow{2}{*}{\multicolumn{2}{|c|}{ Model }} & \multicolumn{2}{|c|}{$\begin{array}{c}\text { Unstandardized } \\
\text { Coefficients }\end{array}$} & \multirow{2}{*}{$\begin{array}{c}\text { Standardized } \\
\text { Coefficients } \\
\text { Beta } \\
\end{array}$} & \multirow[b]{2}{*}{$\mathrm{t}$} & \multirow[b]{2}{*}{ Sig. } \\
\hline & & $\mathrm{B}$ & Std. Error & & & \\
\hline \multirow[t]{6}{*}{1} & (Constant) & 3.045 & 3.806 & & .800 & .428 \\
\hline & Advertising & .351 & .192 & .316 & 1.830 & .074 \\
\hline & Sales Promotion & .025 & .123 & .027 & .201 & .842 \\
\hline & Public Relations & .238 & .199 & .205 & 1.200 & .236 \\
\hline & Personal Selling & .230 & .129 & .262 & 1.781 & .081 \\
\hline & Direct Marketing & -.152 & .169 & -.156 & -.903 & .371 \\
\hline
\end{tabular}

a. Dependent Variable: Customers' Choice

\section{Model Summary}

\begin{tabular}{|l|c|r|r|c|}
\hline Model & $\mathrm{R}$ & R Square & $\begin{array}{c}\text { Adjusted R } \\
\text { Square }\end{array}$ & $\begin{array}{c}\text { Std. Error of the } \\
\text { Estimate }\end{array}$ \\
\hline 1 & $.507^{\mathrm{a}}$ & .257 & .178 & 3.70848 \\
\hline
\end{tabular}

a. Predictors: (Constant), Direct Marketing, Sales Promotion, Personal Selling, Public Relations, Advertising

\section{ANOVA $^{\mathrm{a}}$}

\begin{tabular}{|ll|r|r|r|c|c|}
\hline Model & & Sum of Squares & df & Mean Square & F & \multicolumn{1}{c|}{ Sig. } \\
\hline 1 & Regression & 224.070 & 5 & 44.814 & 3.259 & $.013^{\mathrm{b}}$ \\
& Residual & 646.383 & 47 & 13.753 & & \\
& Total & 870.453 & 52 & & & \\
\hline
\end{tabular}

a. Dependent Variable: Customers' Expense

b. Predictors: (Constant), Direct Marketing, Sales Promotion, Personal Selling, Public Relations, Advertising 